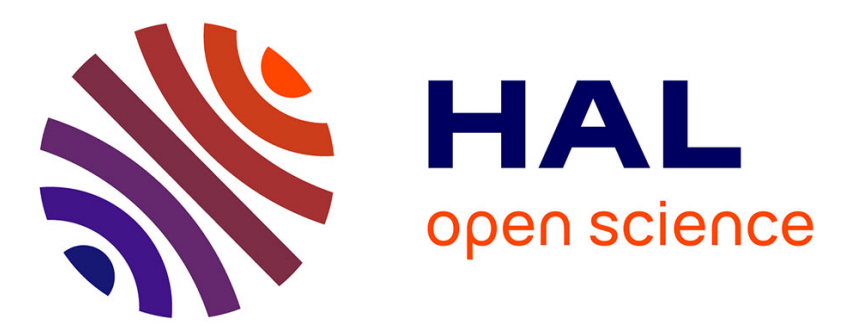

\title{
Synthesis of 3-substituted indolizidines from amino-ynones derivatives
}

Huy-Dinh Vu, Jacques Renault, Thierry Roisnel, Nicolas Gouault, Philippe

Uriac

\section{- To cite this version:}

Huy-Dinh Vu, Jacques Renault, Thierry Roisnel, Nicolas Gouault, Philippe Uriac. Synthesis of 3-substituted indolizidines from amino-ynones derivatives. Tetrahedron Letters, 2016, 57 (27-28), pp.3036-3038. 10.1016/j.tetlet.2016.05.108 . hal-01334050

\section{HAL Id: hal-01334050 https://hal-univ-rennes1.archives-ouvertes.fr/hal-01334050}

Submitted on 11 Oct 2016

HAL is a multi-disciplinary open access archive for the deposit and dissemination of scientific research documents, whether they are published or not. The documents may come from teaching and research institutions in France or abroad, or from public or private research centers.
L'archive ouverte pluridisciplinaire HAL, est destinée au dépôt et à la diffusion de documents scientifiques de niveau recherche, publiés ou non, émanant des établissements d'enseignement et de recherche français ou étrangers, des laboratoires publics ou privés. 


\section{Synthesis of 3-substituted indolizidines from amino-ynones derivatives}

Huy-Dinh Vu, ${ }^{[\mathrm{a}, \mathrm{b}]}$ Jacques Renault, ${ }^{*[\mathrm{a}]}$ Thierry Roisnel, ${ }^{[\mathrm{c}]}$ Nicolas Gouault, ${ }^{[\mathrm{a}]}$ and Philippe Uriac ${ }^{[\mathrm{a}]}$

${ }^{[a]}$ Produits Naturels, Synthèse et Chimie Médicinale, UMR 6226, Institut des Sciences Chimiques de Rennes, Université de Rennes 1, 2, Avenue du Pr Léon Bernard, 35043 Rennes Cedex, France

Fax: +33-2-23234425

*E-mail: jacques.renault@univ-rennes1.fr (J. Renault)

http://www.scienceschimiques.univ-rennes1.fr/equipes/pnscm

${ }^{[b]}$ Department of Chemistry, Vietnam Forestry University, Hanoi, Vietnam

${ }^{[c]}$ Institut des Sciences Chimiques de Rennes, Centre de Diffractométrie X, UMR 6226 CNRS-

Université de Rennes 1, F-35042 Rennes Cedex, France

\section{Abstract}

Two types of indolizidine derivatives can be synthesized from amino-ynones. In the presence of methanesulfonic acid, Meyer-Schuster rearrangement furnished vinylogues of indolizidin-3-ones whereas treatment with zinc chloride gave stable 3-alkynyl-1,5,6,7,8,8a-hexahydroindolizine-zinc complexes that were reduced to 3-alkynylindolizidines.

\section{Graphical Abstract}

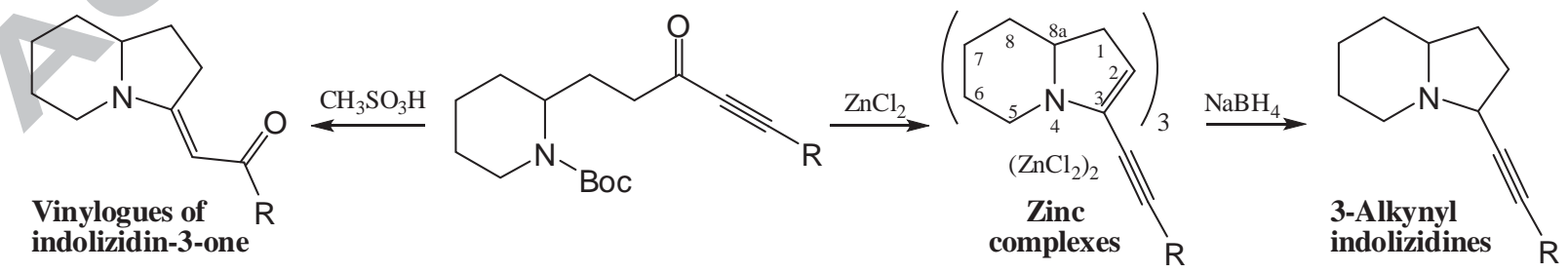

Keywords: amino-ynone, indolizidine, methanesulfonic acid, zinc chloride 
In previous publications, ${ }^{1,2}$ the reactivity of ynones bearing $N$-Boc protected primary amines $\mathbf{I}$ in the presence of electrophilic reagents was reported. Treatment with methanesulfonic acid $\left(\mathrm{CH}_{3} \mathrm{SO}_{3} \mathrm{H}\right)$, gave pyrrolidine exocyclic vinylogous amides via Meyer-Schuster rearrangement, ${ }^{1}$ whereas zinc chloride $\left(\mathrm{ZnCl}_{2}\right)$ furnished acetylenic cyclic imines. In both cases a cyclic carbinolamine intermediate was formed, which underwent either a Meyer-Schuster rearrangement with protic acid ${ }^{1}$ or dehydration with Lewis acid. ${ }^{2}$

In this paper, we present an extension of this study to amino-ynones having a secondary Boc-protected amine. Thus, when applied to the piperidine derivatives II, reaction with $\mathrm{CH}_{3} \mathrm{SO}_{3} \mathrm{H}$ or $\mathrm{ZnCl}_{2}$ resulted in formation of vinylogues of indolizidin-3-ones III or very stable cyclic enamine-zinc complexes. Reduction of these complexes led to the indolizidines $\mathbf{I V}$, which are frequently found as key structural components of numerous bioactive alkaloids (Fig. 1). ${ }^{3}$

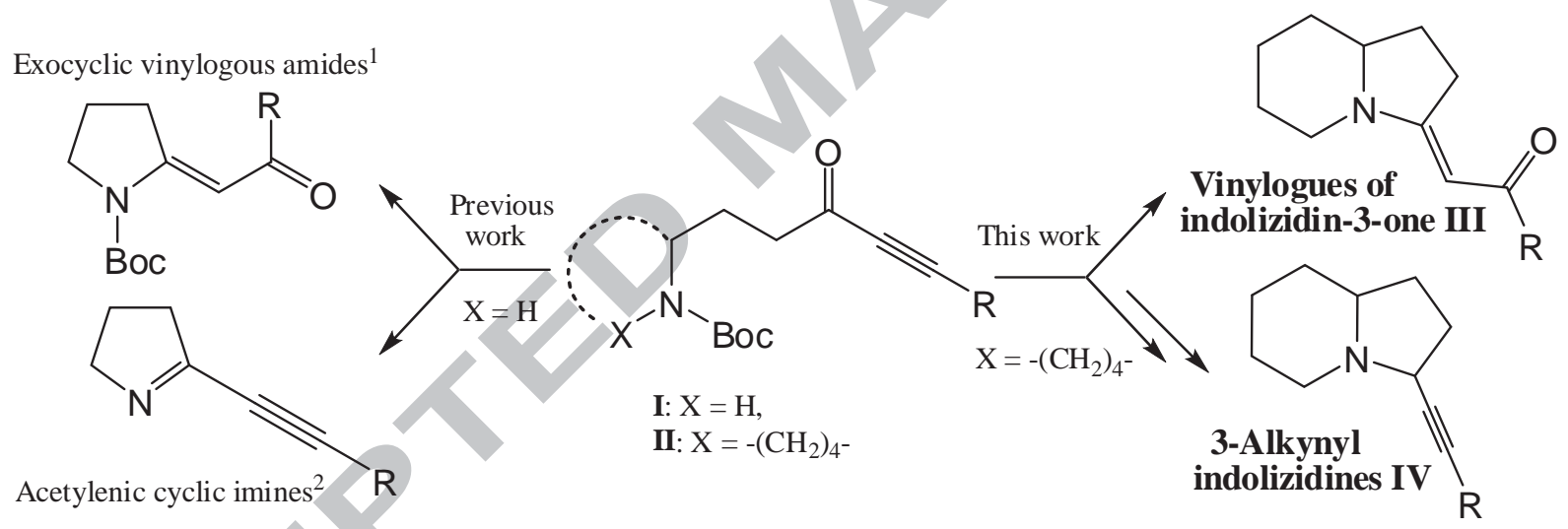

Figure 1. Overall aim of this work.

The starting amino-ynones were easily prepared from racemic pipecolic acid. The method included transformation of the carboxylic acid to an aldehyde, Wittig chain elongation, alkene hydrogenation ${ }^{4}$ and conversion to the racemic Weinreb amide $\mathbf{1}$. Reaction of $\mathbf{1}$ with acetylides ${ }^{5}$ allowed isolation of compounds $\mathbf{2}$ to $\mathbf{5}$ in good yields (> 80\% from Weinreb amide $\mathbf{1}$, Scheme 1). 


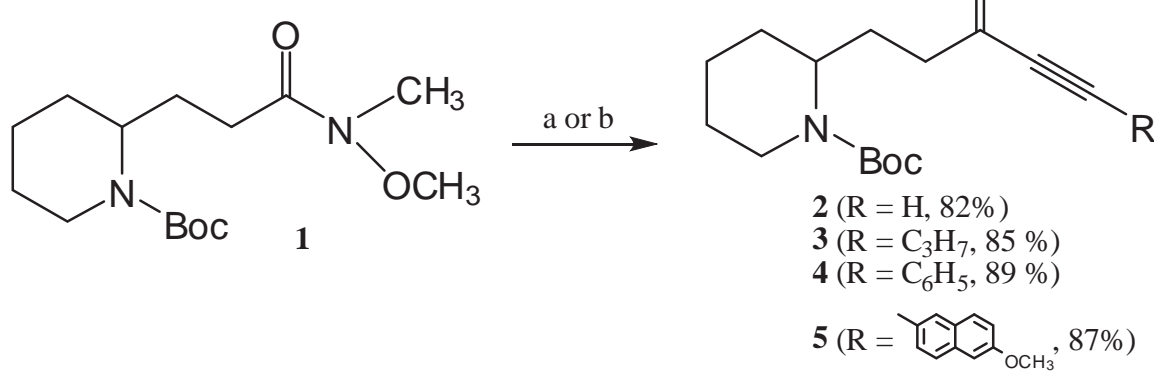

Scheme 1. Synthesis of starting materials 2 to 5. Reagents and conditions: (a) $\mathrm{H}-\mathrm{C} \equiv \mathrm{CMgBr}, \mathrm{THF}$, $0{ }^{\circ} \mathrm{C}$; (b) R-C $=\mathrm{CH}, n \mathrm{BuLi}$, THF, $-50^{\circ} \mathrm{C}$.

Compounds 2-5 were then submitted to reaction with either methanesulfonic acid or zinc chloride. Five equivalents of methanesulfonic acid were used to perform the $\mathrm{N}$-Boc deprotection. The mixture was then made alkaline with sodium or potassium carbonate, leading to formation of the indolizidin-3one vinylogues 6-8 through a Meyer-Schuster rearrangement ${ }^{1}$ (Scheme 2). The very poor yield observed for compound $6(\mathrm{R}=\mathrm{H})$ either under our conditions or those reported by Georg $(\mathrm{HCl}$ in dioxane then $\left.\mathrm{Na}_{2} \mathrm{CO}_{3}\right)^{5 \mathrm{~b}}$ is presumably due to its instability; numerous degradation products were observed by TLC analysis.

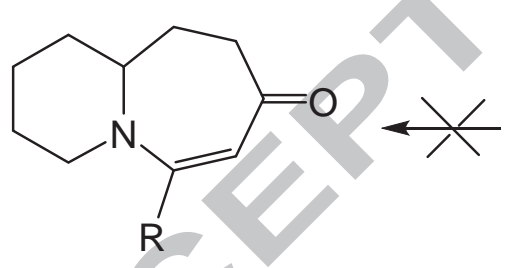

Seven membered enaminone

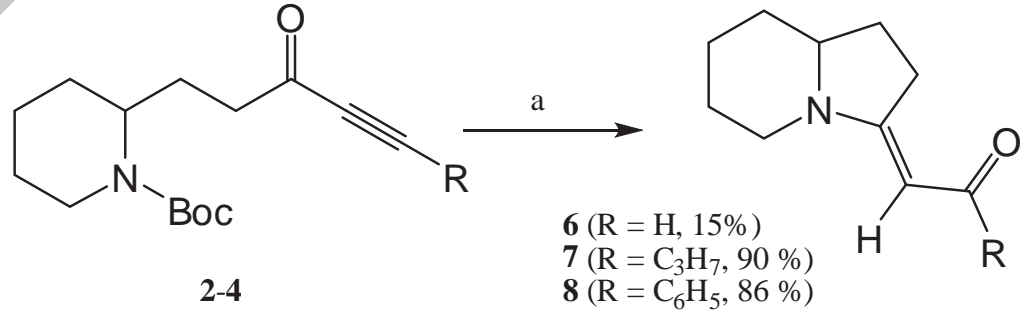

$7\left(\mathrm{R}=\mathrm{C}_{3} \mathrm{H}_{7}, 90 \%\right)$
$\mathbf{8}\left(\mathrm{R}=\mathrm{C}_{6} \mathrm{H}_{5}, 86 \%\right)$ R

Scheme 2. Synthesis of amide vinylogues 6-8. Reagents and conditions: (a) $\mathrm{CH}_{3} \mathrm{SO}_{3} \mathrm{H}$ (5 equiv), $\mathrm{CH}_{2} \mathrm{Cl}_{2} / \mathrm{CH}_{3} \mathrm{OH}, \mathrm{RT}, 4 \mathrm{~h}$ then $\mathrm{Na}_{2} \mathrm{CO}_{3}, 12 \mathrm{~h}$.

Contrary to a previous report, ${ }^{5 b}$ that described formation of seven-membered enaminones under similar conditions, we obtained indolizidine vinylogous amides 6-8, whose derivatives are seldom reported. ${ }^{6}$ Structural assignment was made on the basis of several key analytical features: the ${ }^{1} \mathrm{H}$ NMR spectrum of $\mathbf{6}$ showed a resonance signal at $\mathbf{9 . 3 8} \mathrm{ppm}$, corresponding to an aldehydic proton that 
would not be observed in a seven member enaminone, which correlates closely with structurally related compounds found in the literature ${ }^{7}$ (Fig. 2).

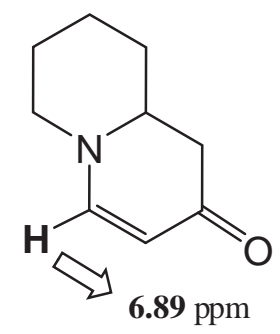

(Comins et al. ${ }^{7 \mathrm{a}}$ )

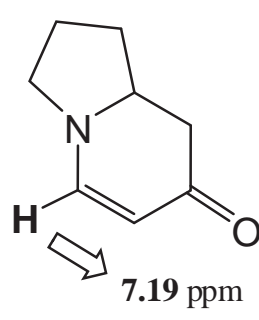

(Georg et al. ${ }^{7 \mathbf{b}}$ )<smiles>CN1CCC/C1=C\C=O</smiles>

(Suzuki et al. ${ }^{\text {7c, } 7 \mathbf{d}}$ )

Figure 2. ${ }^{1} \mathrm{H}$ NMR data of compounds related to 6-8.

The ${ }^{1} \mathrm{H}$-coupled ${ }^{13} \mathrm{C}$ NMR spectrum of $6(\mathrm{R}=\mathrm{H})$ showed a doublet $(J=158.9 \mathrm{~Hz})$ at $187.0 \mathrm{ppm}$, in accordance with an aldehydic carbonyl. NOESY correlation between the H5 and the ethylenic $\mathrm{H}$ confirmed the $E$ configuration of the $\mathrm{C}=\mathrm{C}$ double bond. Finally, the X-ray crystal data of compound $\mathbf{8}$ (Fig. 3) were in accordance with these findings. ${ }^{8}$

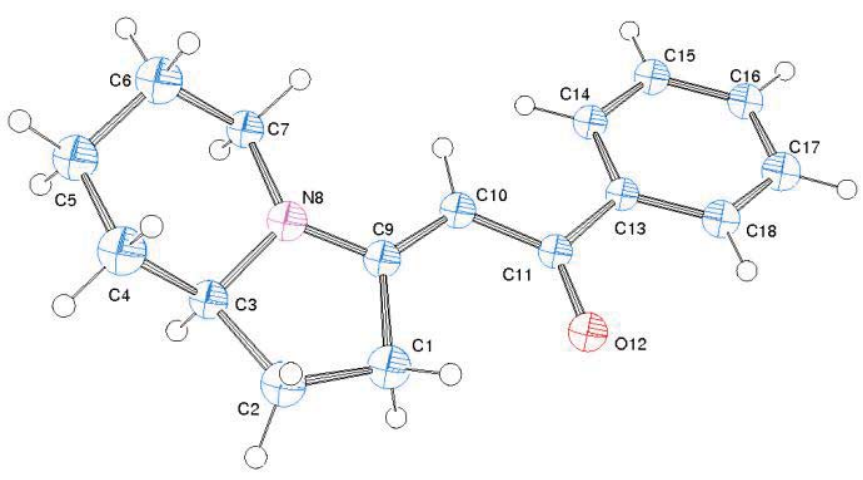

Figure 3.ORTEP drawing of the X-ray crystal structure of 8.

The reactivity of 3-5 with $\mathrm{ZnCl}_{2}$ was then studied (Scheme 3). Conditions of a previous study ${ }^{2}$ were used: treatment with $1 \mathrm{M} \mathrm{ZnCl}$ solution (5 equiv) in diethyl ether quantitatively gave 1,5,6,7,8,8aindolizidines 9-11 as $\mathrm{ZnCl}_{2}$-complexes which were stable and could be stored under anhydrous conditions for months. As in our previous paper, ${ }^{2}$ only degradation occurred with amino-ynone 2 (R = $\mathrm{H})$. The NMR data unambiguously indicated an enamine function: the $\mathrm{CH}$ in the $\beta$-position relative to the nitrogen atom was shielded $(\delta \mathrm{H} 2=4.5 \mathrm{ppm}$ and $\delta \mathrm{C} 2=70 \mathrm{ppm})$ and the $\mathrm{C}$ in the $\alpha$-position was 
deshielded $(\delta \mathrm{C} 3 \cong 163 \mathrm{ppm}) .{ }^{9}$ Elemental analysis performed with 11 was in accordance with a $\mathrm{M}_{3} \mathrm{~L}_{2}$ zinc complex structure (see SI). As enamine reduction needs a protic medium in order to form an iminium salt, ${ }^{9}$ we attempted direct reduction of these complexes using $\mathrm{NaBH}_{4}{ }^{10}$ in ethanol. The 3alkynylindolizidines 12-14 were obtained as a 60/40 mixture of diastereomers, with the major isomers (12a-14a) having H3 and H8a configured cis. This configuration was assigned on the basis of NOESY correlations between H3, H8 and the axial H5 in compound 14a (See SI). Also of note was shielding of the equatorial H5 by the acetylenic substituent in the major isomers (Scheme 3). The yields of the isolated compounds were strongly affected by alkyne substituent $\mathbf{R}$ and isolation was complicated by difficult chromatographic separation. The best result (63\% for 14) was obtained with a bulky 5methoxynaphtyl group that facilitated chromatographic purification.

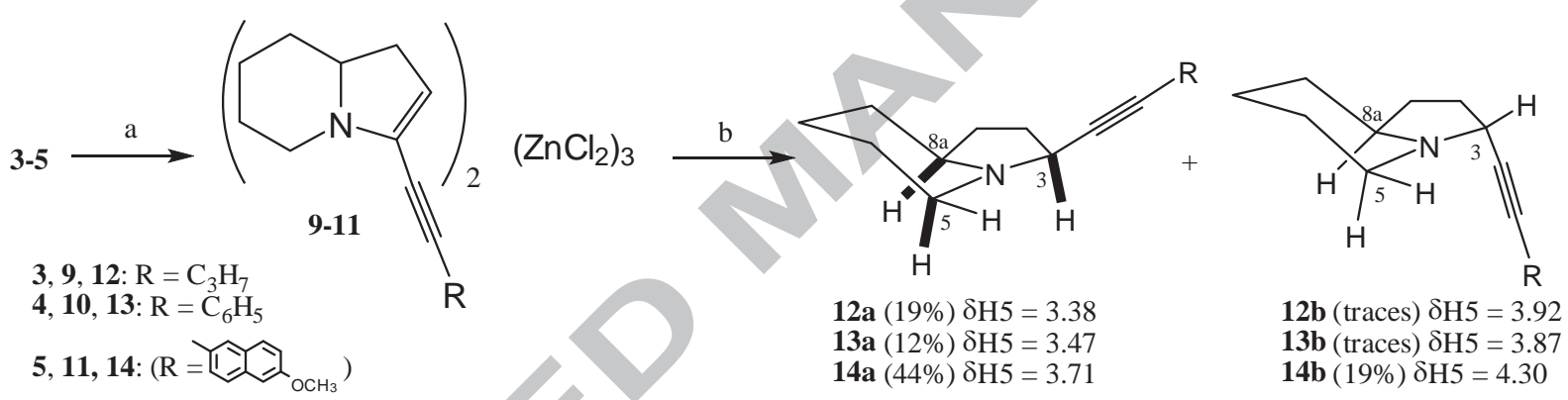

Scheme 3. Synthesis of zinc complexes 9-11 and their reduction to 12-14. Reagents and conditions:

(a) $1 \mathrm{M} \mathrm{ZnCl}_{2}$ in diethyl ether (5 equiv), RT, 12 h; (b) $\mathrm{NaBH}_{4}$ (6 equiv), $\mathrm{C}_{2} \mathrm{H}_{5} \mathrm{OH}, 3 \mathrm{~h}$.

The use of enantiopure pipecolic acid would allow for natural product and analogs synthesis. For example, trans natural indolizidines such as (3,9E)-3-propylindolizidine $\mathbf{V}$ found in the venom of the ant Myrmicaria melanogaster ${ }^{3 i}$-as well as its diastereomer (3,9Z) VI- would be accessible through this strategy (scheme 4):

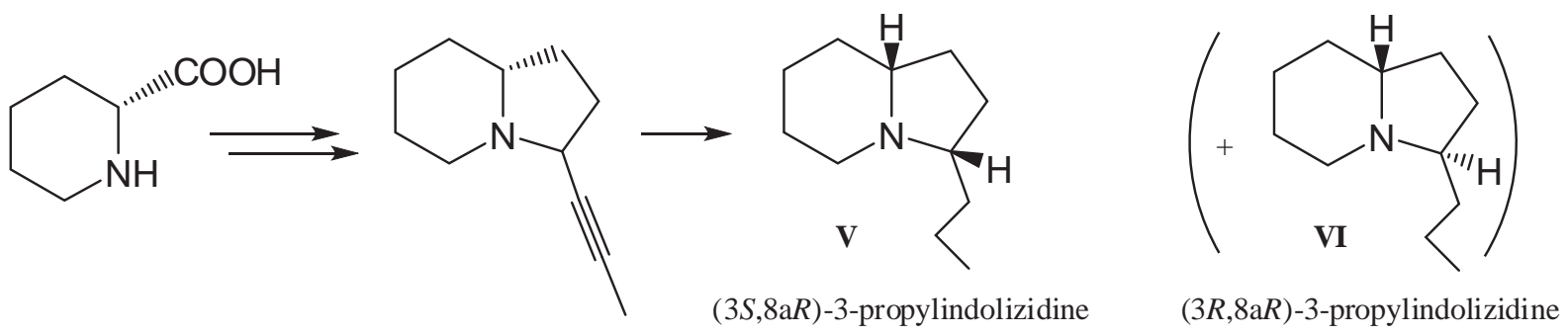

Scheme 4. Possible synthesis of natural indolizidines V and VI 
This study demonstrates access to indolizidines from racemic pipecolic acid with amino-ynones 2-5 as key intermediates. Treatment of 2-5 with methanesulfonic acid furnished indolizinones vinylogues 68, whose chemical structures were unambiguously established. When $\mathrm{ZnCl}_{2}$ was used, enamines 9-11 could be isolated as stable zinc complexes, and subsequent hydride reduction gave 3alkynylindolizidines 12-14 which are not often described in the literature. ${ }^{11}$

\section{Acknowledgments}

The authors are deeply grateful to Fabian Lambert (CRMPO) for X-ray analyses, to the Ministry of Education and Training of Vietnam for financial support and to Daniel Best for his contribution to this work.

\section{Supplementary data}

Supplementary data associated with this article can be found, in the online version, at http....

\section{References and notes}

1.Vu, H.-D.; Renault, J.; Roisnel, T.; Gouault, N.; Uriac, P. Eur. J. Org. Chem. 2014, 4506.

2. Vu, H.-D.; Renault, J.; Roisnel, T.; Robert, C.; Jéhan, P.; Gouault, N.; Uriac, P. Eur. J. Org. Chem. 2015, 4868.

3. For recent publications, see: (a) Gajare, V. S.; Khobare, S. R.; Datrika, R.; Reddy, K. S.; Rajana, N.; Babu, B. K.; Rao, B. V.; Kumar, U. K. S. Tetrahedron Lett. 2016, 57, 1486; (b) Hu, Y.; Zhang, C.; Wang, Y.; Feng, D.; Zhang, M.; Xie, H. J. Nat. Prod. 2016, 79, 252; (c) Teodoro, B. V. M.; Correia, J. T. M.; Coelho, F. J. Org. Chem. 2015, 80, 2529; (d) Moralles-Chamorro, M.; Meza-Gonzales, J.; Cordero-Vargas, A. Tetrahedron Lett. 2015, 56, 4892; (e) Wang, X. G.; Wang, A. E.; Huang, P. Q. Chin. Chem. Lett. 2014, 25, 193; (f) Kauloorkar, S. V.; Jha, V.; Kumar, P. RSC Adv. 2013, 3, 18288. For reviews, see: (g) Brandi, A.; Cardona, F.; Cicchi, S.; Cordero, F. M.; Goti, A. Chem. Eur. J. 2009, 15, 7808; (h) Michael, J. P. Nat. Prod. Rep. 2008, 25, 139; (i) Jones, T. H.; Voegtle, H. L.; Miras, H. L.; Weatherford, R. G.; Spande, T. F.; Garaffo, H. M.; Daly, J. W.; Davidson, D. W. Snelling, R. R. J. Nat. Prod. 2007, 70, 160; (j) Daly, J. W.; Spande, T. F.; Garaffo, H. M. J. Nat. Prod. 2005, 68, 1556; (k) Mitchinson, A.; Nadin, A. J. Chem. Soc. Perkin Trans. 1 2000, 2862.

4. Poon, C. Y.; Chiu, P. Tetrahedron Lett. 2004, 45, 2985. 
5. (a) Adlington, R. M.; Baldwin, J. E.; Catterick, D.; Pritchard, G. J. J. Chem. Soc., Perkin Trans. 1 1999, 855; (b) Niphakis, M. J.; Turunen, B. J.; Georg, G. I. J. Org. Chem. 2010, 75, 6793.

6. (a) Gugelchuk, M. M.; Hart, D. J.; Tsai, Y.-M. J. Org. Chem. 1981, 46, 3671; (b) Hart, D. J.; Tsai, Y.-M. J. Org. Chem. 1982, 47, 4403; (c) Edwards, O. E.; Greaves, A. M.; Sy, W.-W. Can. J. Chem. 1988, 66, 1163; (d) Snyder, S. A.; Kontes, F.; El Sahly, A. M. Heterocycles 2012, 84, 265.

7. (a) Comins, D. L.; LaMunyon, D. H. J. Org. Chem. 1992, 57, 5807; (b) Turunen, B. J.; Georg, G. I. J. Am. Chem. Soc. 2006, 128, 8702; (c) Suzuki, K.; Ohkuma, T.; Tsuchihashi, G.-I. J. Org. Chem. 1987, 52, 2929; (d) Suzuki, K.; Ohkuma, T.; Tsuchihashi, G.-I. J. Org. Chem. 1988, 53, 4160.

8. CCDC 1474017 (compound 8) contains the supplementary crystallographic data for this paper. These data can be obtained free of charge from The Cambridge Crystallographic Data Centre via www.ccdc.cam.ac.uk/data request/cif.

9. Cook, A. G. In Enamines: Synthesis, Structure, and Reactions; Marcel Dekker, Inc. New York, 1988.

10. Nagase, H.; Yamamoto, N.; Nemoto, T.; Yoza, K.; Kamiya, K.; Hirono, S.; Momen, S.; Izumimoto, N.; Hasebe, K.; Mochizuki H.; Fujii, H. J. Org. Chem. 2008, 73, 8093.

11. (a) Dhudshia, B.; Cooper, B. F. T.; Macdonald, C. L. B.; Thadani, A. N. ChemCommun. 2009, 463; (b) Holmes, M.; Crater, A. K.; Dhudshia, B.; Thadani, A. N.; Ananvoranish, S. Exp. Parasitol. 2011, 127, 370. 


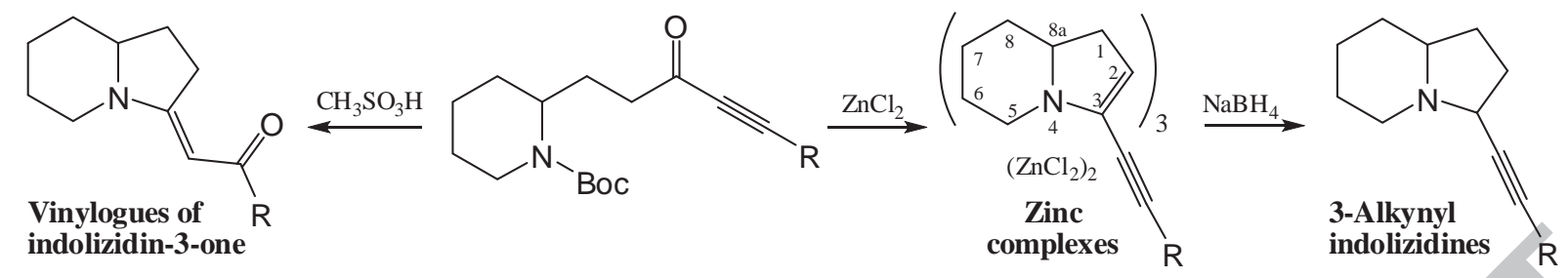

indolizidin-3-one

Zinc
complexes

3-Alkynyl

indolizidines $R$ 
Indolizidine derivatives were efficiently obtained from amino-ynones.

With methane sulfonic acid, amino-ynones furnished vinylogues of indolizidin-3-ones.

In the presence of zinc chloride cyclization of amino-ynones produced stable enynes zinc complexes.

Reduction of enynes zinc complexes produced 3-alkynyl indolizidines. 